\title{
SEEKING AND EVALUATING THE REGULATIONS OF INDONESIA'S EXCLUSIVE ECONOMIC ZONE
}

\author{
Ida Kurnia* and Imelda Martinelli**
}

Department of International Law, Department of Civil Law

Faculty of Law, Universitas Tarumanagara, Jakarta

Jalan Letjen S. Parman, Grogol, Jakarta 11440

\section{Abstract}

Regulation is the cornerstone for utilizing marine fisheries resources, and thus Indonesian Government had implemented its Constitution as basic laws and rules. Those regulations need further elaboration. Therefore, Indonesian Government established sets of laws related to the utilization of marine fisheries resources, and in its implementation, those laws and regulations should never deviate from the Constitution of the Republic of Indonesia. The utilization of marine fisheries resources in Indonesia's Exclusive Economic Zone enables the possibility of cooperation and colaboration with other countries. Therefore, Indonesia is required to seek by evaluating and complementing the laws in accordance with its Constitution.

Keywords: regulation, EEZ, evaluating and seeking.

\section{Intisari}

Pengaturan merupakan landasan utama pemanfaatan sumber daya perikanan, Indonesia telah menyiapkan aturan dasar yaitu Landasan Konstitusional. Pengaturan tersebut perlu penjabaran lebih lanjut. Oleh karena itu Indonesia membentuk aturan-aturan yang terkait dengan pemanfaatan sumber daya ikan dan dalam implementasinya aturan tersebut tidak boleh menyimpang dari aturan yang paling dasar. Pemanfaatan sumber daya ikan di Zona Ekonomi Eksklusif adalah pemanfaatan yang memungkinkan adanya pemanfaatan berbagi dengan negara lain maka Indonesia dituntut untuk segera dapat mencari dengan cara mengevaluasi dan melengkapi aturan sesuai dengan Landasan Konstitusional.

Kata Kunci: Pengaturan, ZEE, evaluasi dan mencari.

\section{Pokok Muatan}

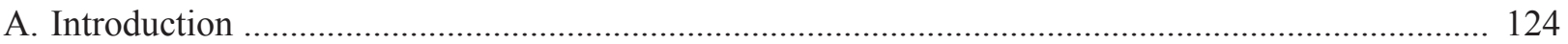

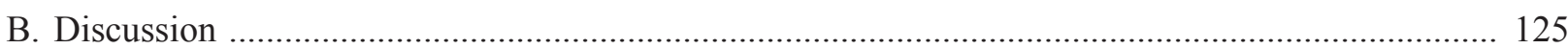

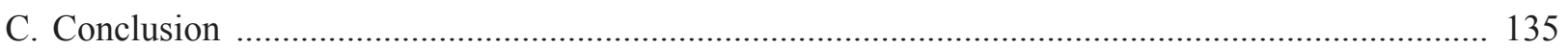

* Correspondence address: idah@fh.untar.ac.id

** Correspondence address: imeldam@fh.untar.ac.id 


\section{A. Introduction}

Indonesia's Exclusive Economic Zone (EEZ), stretched far and wide with diverse marine fisheries resources, must be protected and preserved as an important asset for national development and to increase the welfare of all Indonesians. Thus marine fisheries resources should be considered as major natural resources, and shall be utilized to support the continuity of Indonesia's economic development.

The statement above is not just an illustration, but a fact widely supported by academics and related organization. This situation can be explained by various facts, as followed: ${ }^{2}$

1. Indonesia is the largest maritime nation, because it has the largest marine region in the world: 5.8 million $\mathrm{km}^{2}$ or $3 / 4$ of Indonesia's area, therefore it's no wonder why Indonesia is regarded as a nation with huge potential in marine resources. ${ }^{2}$ According to Indonesia's Law No. 43 of 2008 on Indonesian Territory ${ }^{3}$ stated that the living space for Indonesia after the enactment of UNCLOS 1982 covers the region of Republic of Indonesia and the region of Indonesia's Territorial Jurisdiction with total area for its marine region of 5.8 million $\mathrm{km}^{2}$, with details as followed: total area of Indonesia's archipelagic marine area and territorial seas: 3.1 million $\mathrm{km}^{2}$, total area of EEZ: 2.7 million $\mathrm{km}^{2}$, and $81290 \mathrm{~km}$ length of coastline. ${ }^{4}$

2. Indonesia, with its EEZ covering 2.7 million $\mathrm{km}^{2}$, is classified as one of the nation with large EEZ, along with United States, Australia, New Zealand, Canada, Soviet Union, Japan, Brazil, Mexico, Chile, Norwegia, India, Philippines, Portugal and Republic of Malagasi ${ }^{5}$ and Indonesia has the sovereign rights for marine resources within its EEZ. Thus, Indonesia has the sovereign rights to perform exploration and exploitation, and carry out the management and conservation of marine natural resources within its EEZ region.

3. Indonesia's marine natural resources within its EEZ region could be considered as huge potential, to be utilized directly and simultaneously act as support for marine fisheries resources throughout Indonesia. That is to say, in terms of national development especially in the realm of fisheries, Indonesia's marine natural resources within its EEZ region have two main functions: as natural resources that could be utilized directly through fishing, and as support for marine fisheries resources throughout Indonesia's waters.

Further affirmation of Indonesia's EEZ as a potential national asset is by receiving recognition from the Head of Marine and Fisheries Research Agency, presented at the opening speech of the National Forum of Fish Resources Utilization Policy in Regional Fisheries Management in collaboration with the National Forum of Fish Resources Conservation Management in Indonesia

\footnotetext{
Fundamental consideration regarding the issuance of Indonesian Government Regulation No. 15 of 1984 on Management of Biological Resouces on Indonesian EEZ (State Gazette of the Republic of Indonesia Year 1984 Number 23, Supplement to State Gazette of the Republic of Indonesia No. 3275).

Idris, "Hukum Laut dan Pengelolaan Perikanan Dalam Kerangka Pelaksanaan Otonomi Daerah", Jurnal Hukum Internasional Unpad, Vol. 1, No. 2, August 2002, p. 114

Indonesian Law No. 43 of 2008 on Indonesian Territory, LNRI of 2008 No. 177, TLNRI No. 4925.

Jawatan Hidro-Oseanografi TNI AL, 2006, Pulau-Pulau Kecil Terluar Negara Kesatuan Republik Indonesia, Markas Besar Angkatan Laut Jawatan Hidro-Oseanografi TNI AL, Jakarta, p. i.

From various sources conclude the 15 countries with large area of EEZ, including Indonesia. See Kementerian Luar Negeri, 2010, "Sejarah
} Rejim Hukum Laut”, No. 35 Tahun III, 15 September-14 October 2010, Tabloid Diplomasi Media Komunikasi dan Interaksi, p. 15. 
on the 3rd of Desember 2009. He said:

Marine fisheries resources in Indonesian sea are considered to have the highest biodiversit. These resources make up at least $37 \%$ of the world's species of fishes. If utilized correctly and does not exceed its carrying capacity and sustainability, Indonesia would be able to produce the maximum sustainable production of approximately 6.4 million tons per year. ${ }^{6}$

These facts, in terms of the administration and managerial issue, need to be taken seriously. Especially the discourse about management from economic developmentalism to ecological and sustainable environment which need to be followed up with a clear direction and unambiguous policy. That is to say, the revamping efforts needs to be evaluated and assessed continuously, especially considering the fact that marine fisheries resources is classifed as renewable resources, and in the realm of EEZ becomes a national and international importance. As a first step, attention should be given towards the legal basis. Namely how Indonesia as a country with vast EEZ filled with natural resources can have a solid foundation in terms of legal implementation?

\section{B. Discussion}

The truth of the matter is, the increasing number of humans and the limited area of land, as well as the "promising" marine fisheries resources available within Indonesia's seas, indicate the need for regulations that will lead to sustainable development. Therefore, some adjustments are needed in the making of regulations and policies of marine fisheries resources in general, and marine fisheries resources within Indonesia's EEZ in particular, due to fact that marine fisheries resources are the main source of biological resources at sea. This is in line with the thinking of Susan Hanna, delivered in her various writings in international journals, which said that the existence of marine life is depicting that the sea has "spirit". When fisheries or marine life are damaged, it means the sea has lost its "spirit". Which means that fisheries are the main indicator of the sea itslef.?

Considering the existing conditions that Indonesia is the largest archipelagic state with an EEZ area of 2.7 million $\mathrm{km}^{28}$ and geographically at a very strategic location flanked by two oceans, Indonesia is "rich" in its fisheries resources. As a result it would not be an exaggeration to say that the glory of Indonesia is in the seas, and with the seas Indonesia would achieve its glory. But ironically, the standard of living of fishermen (communities that are directly related to the marine fisheries resources) are mostly below the poverty line. This condition must not be tolerated and it is necessary to revamp the system of fisheries regulations and policies, especially policies concerning fish resources within Indonesia's EEZ.

Regulating the development of fisheries industry in EEZ becomes important. Keeping in mind that an estimated $90 \%$ of commercial fish got caught in the EEZ region. ${ }^{9}$ In addition, the provisions of international law (UNCLOS 1982) which stated that coastal state are able to utilize and harvest its fisheries resources within its EEZ, but when there is a surplus, the surplus must be shared with other countries. It can be said that by implementing the principle of common heritage of nations in the EEZ, there is an option in its settings, i.e. if a coastal state can utilize the resources of fish found in the EEZ fully, so that there is no surplus, then there is no obligation for that coastal state to share its fisheries resources to other countries. Conversely, if a coastal state cannot utilize its fisheries resources entirely within its EEZ, which means there is still

Head of Research Marine and Fisheries Affairs, Opening Speech for the National Forum of Regulation on Marine Fisheries Resources Utilization within Indonesian Waters in collaboration with National Forum of the Conservation and Management of Fish Resources in Indonesia, $3^{\text {rd }}$ Desember 2009.

Arif Satria, 2009, Pesisir dan Laut untuk Rakyat, IPB Press, Bogor, p. 93.

Markas Besar Angkatan Laut Jawatan Hidro-Oseanografi TNI-AL, Loc.cit.

Jon Van Steenis, 2002, "Pirates as Poachers: International Fisheries Law and The Bluefin Tuna", Capital University Law Review, p. 1. See also Francisco Orrego Vicuna, 1984, The Exclusive Economic Zone, A Latin American Perspective, Westview Press, Colorado, pp. $143-158$. 
a surplus, then that coastal state should provide the opportunity for other countries to be able to utilize its fisheries resources in its EEZ.

Conceptually, sustainable development and utilization of marine fishries resources in Indonesia's EEZ are reserved for the welfare of Indonesians. Which means to improve the welfare of the people, it is necessary to achieve sustainable development, including the utilization of marine fisheries resources optimally and responsibly. To discuss this topic holistically, it would be wise to start from the first time a policy had been applied in Indonesia in order to provide the utilization of excess (surplus) marine fisheries resources to other countries.

History shows that Indonesia had involved other countries in various ways and with various consequences, in order to utilize its marine fisheries resources within Indonesia's EEZ. In practice, Indonesian Government observe the rights of fisheries resource and noticed that other countries may be permitted if the Total Allowable Catch (TAC) exceeded Indonesia's National Capacity to Harvest $(\mathrm{NCH})$, Indonesia's ability to utilize its marine resources properly. Thus, in implementing the rights of utilization of fish resources, Indonesia is obliged to consider the interests or rights of other countries.

Based on meeting the needs of the people for sustainable marine fisheries resources, national interests, and the interests of foreign countries, Indonesia is required to determine its Total Allowable Catch (TAC) and determine its National Capacity to Harvest (NCH) within its EEZ region. The purpose of determining the TAC and $\mathrm{NCH}$ are to figure out:

1. The population of fish that are at a level that can provide sustainable catches that any utilization of marine natural resources should take into account aspects of sustainability based on the aspects of conservation.

2. As a further consequence of implementing TAC and $\mathrm{NCH}$, is to determine whether or not there is a surplus. If a coastal state does not have the sufficient ability to harvest the TAC entirely, that means there is a difference between TAC and $\mathrm{NCH}$. The surplus of marine fisheries resources would be of international interests, and Indonesia is obliged to consider the interests or rights of other countries.

Based on the surplus, it means other countries have the right of access to the utilization of fisheries resources in Indonesia's EEZ, and in practice, the necessary requirements needed are stated in an agreement based on implemented regulations with regards to certain factors. Basically, access given by coastal state for foreign countries is in accordance with the principle of balance of interests regarding the utilization of marine fisheries resources in the EEZ.

In practice, in the period after Indonesia ratified UNCLOS 1982 (Act No. 17 of 1985), the government has made several actions in granting permissions to other countries or foreign party, classified by the writer of this paper in three periods based on the underlying legislation, as follows:

1. When Indonesian Government Ratified UNCLOS in 1982 up until 1990.

2. At the time of issuance of the Ministerial Decree of Maritime and Fisheries Affairs No. 815/Kpts/IK.120/11/1990 concerning the Licensing of Fisheries Industry and Ministerial Decree of Maritime and Fisheries Affairs No. 816/Kpts/IK.120/11/1990 concerning the Use of Foreign Flagged Fishing Vessels by way of Rent To Catch Fish in Indonesia's EEZ, valid on the $1^{\text {st }}$ of November 1990.

3. At the time of issuance of the Ministerial Decree of Maritime and Fisheries Affairs No. 995/Kpts/IK.210/9/1999 
concerning the Potential of Marine Fisheries Resources and Total Allowable Catch (TAC) in Indonesia's seas and fisheries region, valid on the $27^{\text {th }}$ of September 1999.

Explanation for the action of granting access and permissions to foreign countries or foreign parties are as follows:

Ad.1. When Indonesian Government ratified UNCLOS in 1982 up until 1990.

In 1985, as a follow up of the ratification of UNCLOS in 1982 and as the implementation of the provisions of Article 62 (2) UNCLOS 1982, Minister of Maritime and Fisheries Affairs issued the Ministerial Decree of Maritime and Fisheries Affairs No. 473a/Kpts/IK.250/6/1985, regulating the Total Allowable Catch (TAC). At that time, the measures taken by Indonesian Government regarding the utilization of marine fisheries resources to other countries were still closed and not yet able to involve foreign countries to utilize the surplus of fisheries resources. Mainly due to the fact that the existing regulation only controls about the types of fish, the potential of each type of fish, and the Total Allowable Catch (TAC) of each type of fish. Whereas the National Capacity to Harvest $(\mathrm{NCH})$ had not been established. ${ }^{10}$

Because the NCH had not yet been established, there was no basis for determining the surplus of marine fisheries resources in Indonesia's EEZ, and in doing so the rights of access to marine fisheries resources by foreign countries could not be implemented. With that in mind, and because EEZ is essentially an international regime and this condition could lead to conflict because other countries also had jurisdiction for the utilization of surplus fisheries resources, Indonesia must followed up immediately.

Ad.2. At the time of issuance of the Ministerial Decree of Maritime and Fisheries Affairs No.815/Kpts/IK.120/11/1990 concerning the Licensing of Fisheries Industry and Ministerial Decree of Maritime and Fisheries Affairs No. 816/Kpts/IK.120/11/1990 concerning the Use of Foreign Flagged Fishing Vessels by way of Rent To Catch Fish in Indonesia's EEZ, valid on the $1^{\text {st }}$ of November 1990.

Because of the lack of infrastructure for properly utilizing its marine fisheries resources within its EEZ region, it was not a surprise that the results obtained were not as expected and underwhelming. This led to the efforts made by Indonesian Government, aimed at improving the utilization of marine fisheries resources in its EEZ region for the benefit of its people. Based on Indonesian Act and Legislation, the government provided the opportunity for other countries to be able to fish and utilize surplus fisheries resources within Indonesia's EEZ, in several way.

\section{a. Joint Venture}

Indonesia's Law No.1 of 1967 on Foreign Investment ${ }^{11}$ had given way and provided opportunities for Joint Ventures in Indonesia, including in the field of fisheries industries. The implementation of Joint Ventures ${ }^{12}$ in the field of fisheries, especially marine fisheries resources within Indonesia's EEZ, were specifically stipulated in Indonesian Governement Regulation No. 15 of 1984 on the Management of Biological Resources in Indonesian EEZ. In Article 2 (3), states that in order to improve its ability to utilize natural resources within Indonesia's

10 UNCLOS III gives opportunity to other countries to utilize the surplus of fish resource within a coastal state's EEZ with regard to Article 69 and Article 70. Ministerial Decree of Marine and Fisheries Affairs No. 473a/Kpts/IK.250/6/1985 on Determining the Total Allowable Catch in Indonesian EEZ, Biro Hukum dan Organisasi Departemen Kelautan dan Perikanan, published in 1985.

11 Indonesian Law No. 1 of 1967 on Foreign Investment, TLNRI No. 2818. Updated to immidiate effect to Indonesian Law No. 25 of 2007 on Foreign Investment, LNRI of 2007 No. 67, TLNRI No. 4724. For Lisence, based on Indonesian Law No. 25 of 2007 on Foreign Investment (see Chapter IV).

12 A joint venture is an association of two or more partners who share the risks and benefits of a commercial, or in some cases, non-profit-venture. See Vladimir Kaezynski and Domonique Le Vieil, 1980, International Joint Ventura in World Fisheries, University of Washington, Seatle, p. 2. 
EEZ, Indonesian or Indonesian legal entity engaged in the realm of Indonesian Fisheries Industries may cooperate with a person or a foreign legal entity in the form of business joint venture or other forms of cooperation in accordance with the legislation in force.

The provisions in Article 2 (3) are linked with the next set of provisions, contained in Article 2 (3), which stated: A foreign person or foreign legal entity may be given the opportunity to engage in fishing in Indonesian EEZ, as long as Indonesian or Indonesian legal entity engaged in the realm of fisheries resources have not been able to fully utilize the Total Allowable Catch (TAC) according to regulations set by the government. In this regard, Ministerial Decree of Maritime and Fisheries Affairs No.815/Kpts/IK.120/11/1990 concerning the Licensing of Fisheries Industry, stated that the head of Ketua Badan Koordinasi Penanaman Modal or Capital Investment Coordinating Board is authorized on behalf of the Minister of Maritime and Fisheries Affairs to grant Ijin Usaha Perikanan (IUP) or Fishing License in the context of foreign investment and domestic investment, Penanaman Modal Asing (PMA) and Penanaman Modal Dalam Negeri (PMDN) ${ }^{13}$ respectively. Based on the Ministerial Decree, there was 41 joint venture business operating and regulated in the fisheries industries up until 1992. ${ }^{14}$

According to Gerald K. Moore, coastal states generally had already implement joint venture partnership policy in its national fisheries regulation. ${ }^{15}$ Likewise, Indonesia had implemented it in the Indonesian Governement Regulation No. 15 of 1984 on the Management of Biological Resources in Indonesian EEZ, followed by the Ministerial Decree of Maritime and Fisheries Affairs No.815/Kpts/IK.120/11/1990 concerning the Licensing of Fisheries Industry. Judging by the legal system underlying the involvement of foreign parties in utilizing marine fisheries resources in the EEZ of Indonesia, as seen with the regulations above, it would seem that the regulations caused disharmony and discord. On one side, joint ventures involving foreign person or foreign parties already occurred, and on the other side there seems to be no basic regulations for determining the surplus of TAC that had not been fully utilizzed by Indonesia, ${ }^{16}$ or regulations that underlied and applicable at that time were not specifically stated about the existence of a surplus and only mentioned the type of fish, their potential, and the TAC. ${ }^{17}$

That particularly caused confusion and lack of guidance for policy makers, because even the application of regulations governing the same field were contradictory. This would open up opportunities to exploit marine fisheries resources with no regard to the availability of fish resources and neglected the factor of sustainability, and could eventually lead to the extinction of fish resources and failure to continuously improve the welfare of the people.

\section{b. Boat Charter}

The new system introduced in order to utilize fish resources in the EEZ of Indonesia

Article 30 of Ministerial Decree of Agriculture affairs No. 815/Kpts/IK.120/11/1990 on Licensing of Fisheries Industries, Biro Hukum dan Organisasi Departemen Kelautan dan Perikanan, published in 1990.

4 Data from BKPM, 1992, Laporan Perkembangan penanaman Modal, BKPM, p. 17.

15 Gerald K. Moore, 1985, Coastal State Requirement for Foreign Fishing, Rome: Food and Agriculture Organization of The United Nations, $\mathrm{p}$ 19.

16 Article 3 jo. Article 9 of Indonesian Government Regulation No. 15 of 1984 on Managing Biological Resources in Indonesian EEZ (State Gazette of the Republic of Indonesia Year 1984 No. 23, Supplement to State Gazette of the Republic of Indonesia No. 3275).

17 Ministerial Decree of Marine and Fisheries Affairs No. 473a/Kpts/IK.230/6/1985 on Determining the Total Allowable Catch in Indonesian EEZ. Biro Hukum dan Organisasi Depertemen Kelautan dan Perikanan, published in 1985.

18 Indonesian Government Regulation No. 15 of 1990 ton Fisheries Business (State Gazette of the Republic of Indonesia Year 1990 No. 19 , Supplement to State Gazette of the Republic of Indonesia No. 3408). 
is the boat renting system, contained in Indonesian Government Regulation No. 15 of 1990 on Fisheries Business. ${ }^{18}$ It was later followed up with its regulation of implementation in the Ministerial Decree of Maritime and Fisheries Affairs No. 816/ Kpts/IK.120/11/1990 on the Use of Foreign Flagged Fishing Vessels by Way of Rent to Catch Fish in Indonesia's EEZ.

The Minister of Marine and Fisheries Affairs issued the decree based on the consideration that Indonesian fishing companies want to increase their capacity to fish in Indonesia's EEZ, and thus they were given the chance to rent foreign flagged fishing ships, after fulfilling the requirements. The requirements that had to be met by Indonesian fishing companies were the ownership of Fishing License or Ijin Usaha Perikanan (IUP), and must be granted the Consent to Use Foreign Ships or Persetujuan Penggunaan Kapal Asing (PPKA). Conversely, foreign flagged fishing vessels used and rented by Indonesian fishing companies must be equipped with a Fishing Permit or Surat Ijin Penangkapan Ikan (SIPI). ${ }^{19}$

The purpose of providing this opportunity is to better utilize the marine fisheries resources in the EEZ of Indonesia for Indonesian fishing companies, by improving their fleets capability to fish with the help of rented foreign flagged fishing vessels. But in reality, it was more of an opportunity for foreign parties and foreign countries to utilize Indonesia's precious marine fisheries resources by freely entering the Indonesian EEZ.

In July 1996, after the deregulation of the fisheries industries, it was estimated that there would be an increase of the number of fleets in Indonesia's EEZ, due to the simplification of the regulations regarding the procedures of procurement of fishing vessels. The inevitable consequences is the EEZ waters and territorial sea may also be invaded by fishing boats. This situation was feared to cause various unfavorable effects, such as over exploitation exceeding the ecological carrying capacity or overfishing, It was a reasonable concern, due to the sheer size of Indonesia's EEZ and the fact that Indonesia was unprepared and lacked clear and proper provisions as well as adequate facilities and infrastructures, and the lack of accurate data involving the massive potential of Indonesia's marine fisheries resources. The data used to express Indonesia's marine resources potential was an estimate value and as if it was speculative value. According to Wenno, a marine researcher from Indonesian Institution of Science or Lembaga Ilmu Pengetahuan Indonesia (LIPI) Ambon, which was cited by A. Zulkani and also cited by Sudirman Saad, said that before heading for deregulation of the fisheries industries, the data of marine resources' potential should first be reviewed. ${ }^{20}$

The simplification of procedures for the procurement of fishing vessels, according to Marhaeni, had several repercussions: ${ }^{21}$

1) With the massive and uncontrolled influx of foreign flagged fishing vessels into Indonesia's EEZ, fishing uncontrollably in the region, Indonesia suffered a huge loss in foreign exchange and national

19 Article 1 of Ministerial Decree of Agricultural Affairs No. 816/Kpts/IK.120/11/1990 on Use of Foreign Flagged Vessels by Way of Rent to Catch Fish in Indonesian EEZ, Biro Hukum dan Organisasi Departemen Kelautan dan Perikanan, published in 1990.

20 A. Zulkani, "Laporan dari Kawasan Timur Indonesia, Perairan ZEE Indonesia Makin Panas", Kompas, 13 Juli 1996, p. 17. See also Sudirman Saad, 2009, Hak Pemeliharaan dan Penangkapan Ikan, Eksistensi dan Prospek Pengaturannya di Indonesia, Yogyakarta, LKiS, p. 9.

21 Marhaeni Ria Siombo, 2010, Hukum Perikanan Nasional dan Internasional, Gramedia Pustaka Utama, Jakarta, p. 100. 
income.

2) Indonesia's marine fisheries resources' sustainability was under threat.

3) In 1996, Indonesian Government carried out Fisheries Industries Deregulation, the substance of which was to open up the opportunity to import fishing vessels, and simultaniously removed the boat renting system, contained in Ministerial Decree of Marine and Fisheries Affairs No.508/Kpts/pl.810/7/1996 on The Procurement of Fishing Vessels and Removal of Renting Foreign Flagged Fishing Vessel.

The decision was aimed to support and improve the capability of Indonesian Fisheries Business and Industries so they can thrive, by removing the operation of foreign vessels in Indonesia gradually until Desember 31, 1999. Although, in practice, it could not be fully achieved due to the fact that national entrepreneurs faced obstacles in financing the procurements of vessels, both imported and local vessels. baik yang impor maupun lokal. Resulting in the act of collusion to manipulate the underlying laws, between various parties, both the government as well as with other entrepreneurs and employers.

\section{c. License}

The involvement of foreign parties in utilizing fisheries resources in Indonesian EEZ was based on the provisions stipulated in Article 62 (2) UNCLOS in 1982, stating that the coastal state can provide access to the surplus of fisheries resources to foreign parties through an agreement or regulation. The involvement of foreign parties in utilizing fisheries resources in Indonesian EEZ, in addition to joint ventures and boat charter, can also be in the form of lisencing agreement.

In the field of fisheries, license can be interpreted as consent. Foreign fishing companies that wants to utilize the fisheries resources in Indonesian EEZ must be authorized. $^{22}$ Fishing permits for foreign owned business, in the form Fishing Permit or Surat Ijin Penangkapan Ikan (SIPI) are issued by the Director General of the Department of Marine and Fisheries Affairs. In the prevailing mechanisms, after a foreign owned business obtained the permit, it can not automatically start fishing in Indonesian EEZ. To be able to do that, foreign owned business with Fishing Permit or SIPI is obliged to appoint a company incorporated within Indonesian Law, and the appointment must be approved by the Minister of Maritime and Fisheries Affairs, or other designated official. ${ }^{23}$ The company incorporated in Indonesia only act as representative and representing the interests of foreign based fishing companies, and it can be said that they act as agent of the foreign based company.

This uneven position is not fair and it made important policies, regarding marine fisheries resources, determined by foreign based fishing business and foreign entrepreneurs. In the end the licensing agreement would only benefit the foreign parties.

From the explanation of the three forms of opportunities given by Indonesian

22 In accordance to regulation regarding permit to utilize fish resources in Indonesian EEZ, a permit might be granted to foreign parties if TAC exceed Indonesian fishing capacity to utilize its resources fully. Lookup: Article 5 section 3 Indonesian Law No. 5 of 1983 on Indonesian EEZ (State Gazette of the Republic of Indonesia Year 1983 No. 44, Supplement to State Gazette of the Republic of Indonesia No. 3260 ).

23 Appointment of Indonesian Company shows that the company incorporated within Indonesian Law act as representative for foreign parties. See Article 15 of Indonesian Government Regulation No. 15 of 1984 on Managing Biological Resources in Indonesian EEZ jo Article 7 of Ministerial Decree of Marine and Fisheries Affairs No. 475/Kpts/IK.120/ 7/1985 on Permit for Foreign Party or Corporation to Fish in Indonesian EEZ (State Gazette of the Republic of Indonesia Year 1984 No. 23, Supplement to State Gazette of the Republic of Indonesia No. 3275) and Biro Hukum dan Organisasi Departemen Kelautan dan Perikanan, published in 1985. 
Government, we can see the synchronicity of laws regarding the marine fisheries resources in Indonesia and the utilization of natural resources within Indonesian EEZ. We could also acknowledge that there is yet to be a regulation that is appropriate and in accordance with the provisions of Article 33 (3) of the 1945 Constitution of the Republic of Indonesia. It would be more accurate to say that the fisheries sub-sector policies have not been able to carry out the direction and mandate given in the National Constitution, especially Article 33 (3) of the 1945 Constitution of the Republic of Indonesia, which would be the utilization of marine fisheries resources oriented to the welfare of the people of Indonesia. Beside that, frequent regulatory changes that underlie the implementation of the utilization of marine fisheries resources in Indonesian EEZ involving foreign party has indicated that there is no basic standard or cornerstone in determining policies that involve foreign parties or foreign cointries.

Ad.3. At the time of issuance of the Ministerial Decree of Maritime and Fisheries Affairs No. Nomor 995/Kpts/IK.210/9/1999 concerning the Potential of Marine Fisheries Resources and Total Allowable Catch (TAC) in Indonesia's seas and fisheries region, valid on the $27^{\text {th }}$ of Setember 1999.

The Ministerial Decree of Maritime and Fisheries Affairs concerning the Potential of Marine Fisheries Resources and Total Allowable Catch (TAC) in Indonesian Region of Fisheries, determined based on the Ministerial Decree of Maritime and Fisheries Affairs No. 995/Kpts/ IK.210/9/1999 is the replacement of the Ministerial Decree of Maritime and Fisheries Affairs No. 473a/ Kpts/IK.250/6/1985 concerning the Determination of Total Allowable Catches within the Indonesian EEZ. This replacement is based on consideration of the utilization and management of fish resources optimally and responsibly, as well as to organize and establish the value of the potential for fish resources and the TAC according to the type of fish and fisheries areas in the territory of the Republic of Indonesia.

Corresponding to the autorithy of coastal states, Indonesia in terms of fisheries areas has distinguish between Indonesian territorial waters under the sovereignity of Republic of Indonesia, and Indonesian EEZ which Indonesia holds the sovereign rights for natural resources within its area, especially biological resources commonly called the "fish". This is in line with international provisions as set out in UNCLOS 1982 that stated: as coastal states, Indonesia has the right and obligation to determine the potential of fish resources that are in its authority.

By chronological order of development, the estimation of the potential of fish resources in some areas of Indonesian fisheries areas as well as the whole fisheries management areas of Indonesia has begun prior to the ratification of UNCLOS in 1982. Overall, the estimation of the potential for Indonesia's marine fisheries resources was first conducted in 1983 by The Directorate General of Biological Resources (Direktorat Bina Sumber Daya Hayati), Directorate General of Fisheries and Marine Fisheries Research Institute (Direktorat Jenderal Perikanan dan Balai Penelitian Perikanan Laut), Agricultural Research and Development Center (Badan Penelitian dan Pengembangan Pertanian), as stated by Tridoyo Kusumastanto and cited by Chairijah with a potential of 6.6 million ton/year. ${ }^{24}$

On Desember 31, 1985, Indonesia officially enacted the Indonesian Law No. 17 of 1985 on the Ratification of The United Nations Convention

24 Tridoyo Kusumastanto's research, cited by Chairijah, 2004, Studi Pengelolaan Sumber Daya Perikanan Laut Indonesia, Gramedia Pustaka Utama Jakarta. See also Chairijah, 2005, Laporan Akhir Penelitian tentang Aspek Hukum Pemanfaatan ZEE dalam rangka Peningkatan Pendapatan Nelayan Indonesia, Pusat Penelitian dan Pengembangan Hukum Nasional Badan Pembinaan Hukum Nasional, Departemen Hukum dan Hak Asasi Manusia, Jakarta, p. 48. 
on the Law of the Sea (Law 17 of 1985), which is commonly referred to as UNCLOS 1982 . What Indonesia need to do now is to take further steps, especially concerning the implementation and follow up on the provisions of UNCLOS 1982 in the country based on national law. This act of implementation was initiated by the issuance of regulations on the establishment of TAC in Indonesian EEZ, contained in the Ministerial Decree of Maritime and Fisheries Affairs No.473a/ Kpts/I.K. 230/6/1985, which set the maritime fisheries resources potential for 2.114.695 million tons per year.

Furthermore, in order to obtain accurate data and information (the best scientific evidence) about the potential of marine fisheries and resources in Indonesia's fisheries areas, Indonesia continued its effort through forums or workshops and national fisheries research involving universities and college. In the first fisheries forum that took place from 19-20 July, 1990, in Sukabumi, Naamin and Hardjamulia have reported an estimated value of fisheries resources of 7.7 million tons per year. Then, the Directorate General of Maritime and Fisheries Affairs oficially published a book entitled "Buku Potensi dan Penyebaran Sumber Daya Ikan di Perairan Indonesia", ${ }^{25}$ or "Book of The Spread and Potential of Fisheries Resources in the Waters of Indonesia". In the book, Tridoyo Kusumastanto stated an alleged value of the potential of fish resouces in Indonesian fisheries areas for 5.7 million tons per year. ${ }^{26}$

In 1995, Fisheries Research and Development Center (Pusat Penelitian dan Pengembangan Perikanan) in collaboration with FAO organized a workshop to discuss the main agenda of recalculating the potential of fisheries resources based on the most recent data available. This workshop resulted in an estimated value of fisheries potential of 3.67 million ton/year. ${ }^{27}$ Furhtermore, the Directorate General of Maritime and Fisheries in collaboration with the Fisheries Research and Development Center of Bogor Institue of Agriculture in 1996 conducted an evalutation of the book "Buku Potensi dan Penyebaran Sumber Daya Ikan di Perairan Indonesia" or "Book of The Spread and Potential of Maritime and Fisheries Resources in Indonesian Waters and Seas" which was later published in the same year (1996). From the results of these evaluations, the alleged value of the potential of fisheries resources in Indonesian waters ${ }^{28}$ is 6.35 million tons per year.

In development for about two years, in the year of 1998, the National Commission for Marine Resources Assessment or Komisi Nasional Pengkajian Sumber Daya Perikanan Laut published a book titled "Buku Potensi dan Penyebaran Sumber Daya Ikan Laut di Perairan Indonesia", or "Book of The Spread and Potential of Maritime and Fisheries Resources in Indonesian Waters and Seas" which is a book based on careful review from various researchers, consisting of Fisheries Research and Development Center (Pusat Penelitian dan Pengembangan Perikanan), Research and Development Center for Oceanology for LIPI (Pusat Pengembangan dan Penelitian Oseanologi LIPI), the Directorate General for Maritime and Fisheries, National Agency for the Assessment and Application of Technology (Badan Pengkajian dan Penerapan Teknologi) and National Administrations for Space Flights (Lembaga Penerbangan Antariksa Nasional). In addition, the National Commission for Marine Resources Assessment or Komisi Nasional Pengkajian Sumber Daya Perikanan Laut also published a book entitled "Potensi, Pemanfaatan dan Peluang Pengembangan Sumber Daya Ikan Laut

\footnotetext{
25 Indonesian Waters include the Indonesian Territorial Sea and Indonesian Inland Water Area. Look up Indonesian Law No. 4 of 1960 on Indonesian Waters (State Gazette of the Republic of Indonesia Year 1960 No. 22, Supplement to State Gazette of the Republic of Indonesia No. 1942).

26 Tridoyo Kusumastanto, 2004, Studi Pengelolaan Sumber Daya Perikanan Laut Indonesia, Gramedia Pustaka Utama, Jakarta, p. 49.

2 Ibid.

28 Indonesian Waters include the Indonesian Territorial Sea and Indonesian Inland Water Area, See Law No. 6 of 1996 on Indonesian Waters (State Gazette of the Republic of Indonesia of 1996 No. 73, Supplement to State Gazette of the Republic of Indonesia No. 3647).

29 Ibid.
} 
di Perairan Indonesia"29 or "Potential, Utilization, and Develpment Opportunity for Marine Fisheries Resources in the Waters of Indonesia". The book contained an alleged value of the potential of fish resources in the waters of Indonesia of 6.26 million ton/year. ${ }^{30}$

Based on the results of the study of National Commission for Marine Resources Assessment in 1998, the Minister of Maritime and Fisheries Affairs issued a Decision on the Potential of Marine Fisheries Resources and Total Allowable Catch (TAC) in Indonesian waters, as contained in the Ministerial Decree of Marine and Fisheries Affairs No. 995/Kpts/IK.210/9/99. The issued decision stated that the Indonesia's fisheries resources in its waters has a potential value of 6.258 million ton/ year ${ }^{31}$ with a value of TAC of 5.006 million ton/ year, and the potentional value of fisheries resources in Indonesian EEZ of 1.858 million tons/year with TAC of 1.487 million tons/year.

The development of determining the potential value that varied is inseperable from the unique nature of fish. In addition to seasonal factors that influenced the fishes, the movement of the fishes themselves contributes to the fact that the results were very heterogeneous.

Ad.4. Agreements Involving Other Countries in Regard of Marine Fisheries Resources

\section{a. Indonesia with China}

The Agreement of the Utilization of Part of TAC in Indonesian EEZ or "Perjanjian Pemanfaatan Bagian JTB di ZEE Indonesia" between Indonesia and China on 19 December $2001^{32}$ and 16 July $2004,{ }^{33}$ was a form of international agreement between two countries that specifically regulate fisheries issues. Both the agreement refers to the mechanisms and procedures of Article 62 UNCLOS 1982. It is explicitly indicated in the objectives of the cooperation agreement, that the purpose of the regulation is to establish mutual cooperation on the basis of principles and procedures on the part of TAC within Indonesian EEZ, as stipulated by the Ministerial Decree of Marine and Fisheries Affairs of Indonesia, can be given towards Chinese Fishing Vessels.

In an agreement about fisheries resources, usually contain certain elements that constitute the terms of fisheries agreements. The terms of fisheries agreement depends on the direction of policy and legislation for related coastal state, as well as the availability of fisheries resources. In general, elements that reflected the requirements and terms should at least contain standard elements as follows:

a. Region, shown with the coordinates of certain sea areas in which the fishing vessels may operate;

b. Number of fishing vessels allowed to operate in territorial sea, port base, and port of loading or certain transit based on the consideration of availability and sustainability of fish resources or allocation;

c. Tonnage of ships allowed to operate;

d. The type and size of fishing gear used;

e. The type and size of fish that may be caught;

f. Number of days of operation;

g. Quota of catches;

h. Report of cathes.

Although, the application of the elements mentioned above are not all implemented in the bilateral fisheries agreement between Indonesia and China in 2001.

In the bilateral fisheries agreements of 2001 , and in protocol amending of the bilateral agreements in 2004, it was not stated and specify the quotas for total fish cathes, quotas per each type of fish, type and allowable number of type of ships,

\footnotetext{
Tridoyo Kusumastanto, Loc.cit.

Ministerial Decree of Marine and Fisheries Affairs No. 995/Kpts/IK.210/9/1999.

Bilateral Arrangement between The Ministry of Marine Affairs and Fisheries of The Republic of Indonesia and The Ministry of Agriculture of The People's Republic of China on The Utilization of Part of The Total Allowable Catch in Indonesian Exclusive Economic Zone signed in Beijing on $19^{\text {th }}$ of December 2001.

33 Protocol Amending the Bilateral Arrangement between The Ministry of Marine Affairs and Fisheries of the Republic of Indonesia and the Ministry of Agriculture of The People's Republic of China on the Utilization of Part of the Total Allowable Catch in Indonesian Exclusive Economic Zone, signed in Beijing on 16 July 2004.
} 
the total ammount of ships in a period of a year, and the number of days of operation, resulting in the Chinese vessels to fish without limit. It could be said that it was a fatal mistake, by not stating the standard terms and elements of a fisheries agreement. Fatally, it might lead to overfishing and could consequently lead to the sustainability and preservation, and could even lead to the extinction of marine fisheries resources.

\section{b. Indonesia with Philippines}

The 2002 bilateral fisheries agreement between Indonesia and the Philippines have a different approach to the bilateral fisheries agreement between Indonesia and China. The 2002 bilateral fisheries agreement between Indonesia and the Philippines did not specifically regulate about fisheries issues as contained in the agreement with China, but rather about the regulation of fisheries in a maritime boundary agreement. ${ }^{34}$ It is explicitly said that access to TAC from Indonesian EEZ in the Sulawesi Sea is authorized, taking into account the need to define the maritime boundaries between the two countries.

In accordance with the field of cooperation based on the consideration stated in the Preamble, which stated that the spirit of UNCLOS 1982 and the common interest of the parties in implementing the sustainable development and management of responsible fisheries, conservation, and utilizing biological marine resources responsibly, Indonesia set the integrated marine and fisheries cooperation or usaha perikanan tangkap terpadu. ${ }^{35}$

To date, the developments related to the bilateral cooperation between Indonesia and the Philippines, despite formed as a "Memorandum of Understanding Between the Government of the Republic of Indonesia and the Government of the Republic of the Philippines on Marine and fisheries Cooperation", there are yet to be concrete measures concerning the marine and fisheries cooperation. In principal, fisheries business entrepreneurs from Philippines still want to invest in Indonesia if provided with protection and legal certainty regarding the capital invested in Indonesia. The difference with the bilateral agreement with China is, Philippines still objects the policy of only Indonesian fishing vessels are allowed in Indonesian jurisdicition.

\section{c. Indonesia with Thailand}

In the details of the section, in terms of the goals related to Article 62 UNCLOS 1982, said that the purpose of this agreement is to create cooperation based on the principles and procedures of access from the TAC of Indonesian EEZ that can be granted to registered and Thailand flagged fishing vessels. When compared with the agreement that have been made by Indonesia, both with China and the Philippines, this bilateral agreement with Thailand are more restricted. This can be seen from the formulation of Article 2 (2), which stated that one fishing vessel is allocated in one fishing ground using one type of fishing gear.

Comprehensive data regarding the number of types of fishing vessels with specific fishing gear and a certain size could be used to calculate the level of its fishing capacity. However, because the data dan information available in Indonesian Fisheries Statistics for the number and type of fishing vessels, as well as the number and types of fishing gear is not (currently) correlated to one another, it can not be known for sure the data regarding the types of fishing vessels using a certain fishing gear, and as a result, difficult to know the fishing capacity. The available statistics only have two types of data: the number of fishing vessel with certain dimension and the number of a certain fishing gear.

The available data dan information above, presented in numbers and statistics, are only used

\footnotetext{
34 Arrangement between The Department of Agriculture of the Republic of the Philippines and the Ministry of Marine Affairs and Fisheries of the Republic of Indonesia on Utilization of Part of the Total Allowable Catch in the Indonesian Exclusive Economic Zone signed in Manila on the 10 January, 2002 (bilateral fisheries agreement of 2002).

35 Article 1 section 3 defined that usaha perikanan tangkap terpadu as the act of integrated fishing marine fisheries resources, or at the very least the act of integrated managemtn of fish resources. See Ministerial Decree of Marine and Fisheries Affairs No. PER.05/MEN/2008 on Fisheries Cooperation, Pusat Data Statistik dan Informasi Departemen Kelautan dan Perikanan, published in 2008.
} 
to merely determine how much is the growth factor for each catagory each year and not used as a basis of calculating the actual fishing capacity in certain areas of Indonesian EEZ.

The Ministry of Maritime and Fisheries Affairs issued a Ministerial Decree of Maritime and Fisheries Affairs KEP 23/MEN/2001 on the Productivity of Fishing Vessels and was changed to Ministerial Decree of Maritime and Fisheries Affairs KEP 38/MEN/2003 on the Productivity of Fishing Vessels, ${ }^{36}$ already covers the basis of calculating the fishing capacity of various types of fishing gears, related to the types of fishing vessels. However, these calculations are only used as a basis for determining the licensing and determining the amount of charges to be paid by fishing vessels measuring over $30 \mathrm{GT}$ and the licensing provisions are under the authority of central government. Even though there are $96 \%$ of the national fishing fleets that are small fishing boats (small scale), not catagorized and included in that specified category.

As a result of the implication of the rules of lisencing, the implication is not necessarily significant and that could barely affect the sustainability of fisheries resources, because the existing laws have not been based on the sustainability of fisheries resources.

Those three international agreements that grant access to the surplus of marine fisheries resources within Indonesian EEZ, made with China, Philippines, and Thailand, showed fatal flaws and irregularities towards the provisions of UNCLOS 1982. Therefore, it needs to be addressed and prepared in accordance with the terms and conditions with Indonesia. With the right and adequate legal tools, international agreements could have major implications towards the national economic growth.

\section{Conclusion}

Regulating, managing, and utilizing marine fisheries resources in a wise and thoughtful manner is a necessity, because a nation's marine region could be affected by the condition of fisheries resources from other marine regions. Which means, in terms of regulating and utilizing marine fisheries resources, it is necessary to do so optimally and with regards to marine preservation.

Therefore, the most favorable circumstances for Indonesian Government is to determine its marine fisheries resources and determine the value of its Total Allowable Catch (TAC) and National Capacity to Harvest (NCH) within Indonesia's Exclusive Economic Zone. Next, the government should seek to implement the Constitution of the Republic of Indonesia Article No. 33 (3) as mandated, by utilizing Indonesia's TAC to its full potential, especially considering the Indonesian people's needs for dependable nutritional source, as well as other national interests such as source of foreign exchange and income.

In terms of the utilization of marine fisheries resources involving foreign party or foreign nations, all elements and contributing factors must take into account both the people's needs and availability of marine fisheries resources. If all elements and contributing factors are applied correctly, then both sustainable development of marine fisheries resources and fullfilment of the people's needs are ensured, without having to interfere with foreign nations access rights regarding the surplus of marine fisheries resources. The implementation would also be based upon UNCLOS 1982. Thus the application for all elements and contributing factors in the regulation of international agreements would cover two requirements, i.e. standard requirements (requirements stated in UNCLOS 1982 Article No. 62), and specific requirements (naturalistic requirements, Indonesia's capability, and other contributing factors such as available infrastructures).

\footnotetext{
36 Revised to Ministerial Decree of Marine and Fisheries Affairs No. KEP.50/MEN/2008 on Fishing Vessels Producivity, that took effect from the $10^{\text {th }}$ of September, 2008. Then revised again based on Ministerial Decree of Marine and Fisheries Affairs No. KEP. 60/MEN/2010 on Fishing Vessels Productivity, that took effect from the $21^{\text {st }}$ of October, 2010, Pusat Data Statistik dan Informasi Departemen Kelautan dan Perikanan, published in 2010.
} 


\section{BIBLIOGRAPHY}

\section{A. Books}

Kusumastanto, Tridoyo, 2004, Studi Pengelolaan Sumber Daya Perikanan Laut Indonesia, Gramedia Pustaka Utama, Jakarta.

Moore, Gerald K., 1985, Coastal State Requirement for Foreign Fishing, Food and Agriculture Organization of the United Nations, Rome.

Saad, Sudirman, 2009, Hak Pemeliharaan dan Penangkapan Ikan, Eksistensi dan Prospek Pengaturannya di Indonesia, LKiS, Yogyakarta.

Satria, Arif, 2009, Pesisir dan Laut Untuk Rakyat., IPB Press, Bogor.

Siombo, Marhaeni Ria, 2010, Hukum Perikanan Nasional dan Internasional, Gramedia Pustaka Utama, Jakarta.

Steenis, Jon Van, 2002, Pirates as Poachers: International Fisheries Law and The Bluefin Tuna, Capital University Law Review, Ohio.

TNI AL, Jawatan Hidro-Oseanografi , 2006, PulauPulau Kecil Terluar Negara Kesatuan Republik Indonesia, Markas Besar Angkatan Laut Jawatan Hidro-Oseanografi TNI AL, Jakarta.

Vicuna, Francisco Orrego, 1984, The Exclusive Economic Zone, A Latin American Perspective, Westview Press, Colorado.

\section{B. Journal Articles}

Idris, "Hukum Laut dan Pengelolaan Perikanan Dalam Kerangka Pelaksanaan Otonomi Daerah", Jurnal Hukum Internasional Unpad, Vol. 1, No. 2, Agustus 2002.

\section{Research Result}

Chairijah, 2005, Laporan Akhir Penelitian tentang Aspek Hukum Pemanfaatan ZEE dalam rangka Peningkatan Pendapatan Nelayan Indonesia, Research Reposrt, Pusat Penelitian dan Pengembangan Hukum Nasional Badan Pembinaan Hukum Nasional, Departemen Hukum dan Hak Asasi Manusia, Jakarta.

\section{Papers/Speech}

Foreign Invesment, Laporan Perkembangan Penanaman Modal, Report, BKPM Jakarta, 1992.

Head of Research Marine and Fisheries Affairs, Opening Speech for the National Forum of Regulation on Marine Fisheries Resources Utilization within Indonesian Waters in collaboration with National Forum of the Conservation and Management of Fish Resources in Indonesia, Speech, National Forum, Departemen Kelautan dan Perikanan, Jakarta, 3 December 2009.

Director of Management of Fisheries Resources, Department of Marine and Fisheries Affairs, Tuna Fisheries Management in Indonesia, $1^{\text {st }}$ ASEAN Tuna Working Group Meeting, Paper, Jakarta, 25-26 May 2011.

\section{E. Newspaper or Magazine Article}

A. Zulkani, "Laporan dari Kawasan Timur Indonesia, Perairan ZEE Indonesia Makin Panas", Kompas, 13 July 1996.

Kementerian Luar Negeri, "Sejarah Rejim Hukum Laut", Tabloid Diplomasi Media Komunikasi dan Interaksi, No. 35, Year III, 15 September-14 October 2010.

\section{F. Government Regulations}

Law No. 4 of 1960 on Indonesian Waters (State Gazette of the Republic of Indonesia Year 1960 No. 22, Supplement to State Gazette of the Republic of Indonesia No. 1942).

Law No. 1 of 1967 on Foreign Investment (State Gazette of the Republic of Indonesia Year 1967 No. 1, Supplement to State Gazette of the Republic of Indonesia No. 2818).

Law No. 5 of 1983 on Indonesian EEZ (State Gazette of the Republic of Indonesia Year 1983 No. 44, Supplement to State Gazette of the Republic of Indonesia No. 3260). 
Law No. 6 of 1996 on Indonesian Waters (State Gazette of the Republic of Indonesia Year 1996 No. 73, Supplement to State Gazette of the Republic of Indonesia No. 3647).

Law No. 25 of 2007 on Foreign Investment (State Gazette of the Republic of Indonesia Year 2007 No. 67, Supplement to State Gazette of the Republic of Indonesia No. 4724).

Law No. 43 of 2008 on Indonesian Territory (State Gazette of the Republic of Indonesia Year 2008 No. 177, Supplement to State Gazette of the Republic of Indonesia No. 4925).

Government Regulation No. 15 of 1984 on Management of Biological Resources on Indonesian EEZ (State Gazette of the Republic of Indonesia Year 1984 No. 23, Supplement to State Gazette of the Republic of Indonesia No. 3275).

Government Regulation No. 15 of 1990 on Fisheries
Business (State Gazette of the Republic of Indonesia Year 1990 No. 19, Supplement to State Gazette of the Republic of Indonesia No. 3408).

Ministerial Decree of Marine and Fisheries Affairs No. 473a/Kpts/IK.250/6/1985 on Determining the Total Allowable Catch in Indonesian EEZ.

Ministerial Decree of Marine and Fisheries Affairs No. 475/Kpts/IK.120/ 7/1985 on Permit for Foreign Party or Corporation to Fish in Indonesian EEZ (State Gazette of the Republic of Indonesia Year 1984 No. 23, Supplement to State Gazette of the Republic of Indonesia No. 3275.

Ministerial Decree of Agricultural Affairs No. 816/ Kpts/IK.120/11/1990 on Use of Foreign Flagged Vessels by Way of Rent to Cath Fish in Indonesian EEZ. 